\title{
Pedagogical and decolonial affordances of group portfolio assessments for learning in South African universities
}

\author{
Ilse Fouche ${ }^{\#}$, Grant Andrews, Laura Dison, and Maria Prozesky \\ University of the Witwatersrand \\ "Corresponding Author: ilse.fouche@wits.ac.za
}

(Submitted: 28 September 2020; Accepted: 8 September 2021)

\begin{abstract}
Our paper discusses our recent experiences with designing effective assessments for challenging local contexts by using group work portfolio projects. South African universities are experiencing ever-increasing student numbers, diverse student bodies which have different language and literacy skill levels, and limited resources. Simultaneously, the need to decolonise university curricula and teaching and learning practices is being actively investigated across South Africa. In this paper, we discuss preliminary steps we have taken towards achieving this broader transformative agenda in the context of the massification of education, namely designing effective and decolonial assessments that support epistemological access and academic success, while at the same time challenging what counts as 'powerful knowledge' (Young and Muller, 2013) in the classroom. We argue that effective decolonial knowledge practices and deep critical engagement can be achieved by using group work portfolio tasks that align with assessment for learning principles (Carless, 2015). Using a designbased research approach, we describe three courses across two universities which have implemented portfolio-type group assessments. The preliminary findings suggest that group projects can yield rich and productive assessment for learning outcomes in large classes. In addition, portfolio projects that purposely interrogate diverse perspectives, knowledges and experiences can harness the diversity of groups to work towards decolonising the classroom.
\end{abstract}

Keywords: assessment for learning, decolonialism, group-learning, massification, portfolios

\section{Introduction}

A wealth of research, from as far back as 50 years ago (Snyder, 1970; Miller and Parlett, 1974) to the present (e.g., Gibbs, 2019; Winstone and Carless, 2020), exists in the field of higher education on student experiences of assessment and their perceptions of assessment demands. What emerged from these studies was that assessment 'completely dominated student experience' and did not help 
students' engagement with their learning (Gibbs, 2019: 22). In an attempt to create learning environments with assessments that deepen students' approaches to learning, we draw on the theory of social constructivism, which 'examines the knowledge and understandings of the world that are developed jointly by individuals', and 'assumes that understanding, significance, and meaning are developed in coordination with other human beings' (Amineh and Asl, 2015: 13). Social constructivism holds that language is central in humans' construction of reality (Leeds-Hurwitz, 2009) and, according to Mckinley (2015), focuses on the sociocultural conventions of Discourses (cf. Gee, 2008). These conventions, inextricably linked firstly to language, and secondly to how individuals relate to existing conversations in academia, include interpreting literature, hedging claims, addressing counter arguments, and citing evidence (Mckinley, 2015). Group work portfolio tasks are an ideal vehicle through which students can work together (learning from one another through conversation) to achieve a greater outcome than would have been possible had they worked in isolation.

In a country as socially, culturally, and linguistically diverse as South Africa, we believe that there is great wealth in the 'social and cultural backgrounds and positionalities' (Mckinley, 2015: 186) that students bring to the classroom, specifically from the perspective of the decolonised classroom. Decolonisation is a complex and contested term; we focus here on epistemological decolonisation, ${ }^{1}$ and argue that in a decolonial classroom the choice is always to foreground indigenous and nonwhitestream knowledges and the people who hold these knowledges, both teachers and students. To take the decolonial option is to question the exclusive claim to the status of knowledge and truth of Western knowledge traditions, and to be open to the possibilities of indigenous knowledge systems that are 'hidden' and 'discredited' under coloniality (Mignolo, 2011: 46). We believe that classroom experiences can be actively generated that enrich all participants in terms of viewing the world through new lenses. This, in turn, has the potential of encouraging novel and epistemologically just ways of knowledge generation. We are particularly interested in how students' diverse backgrounds and positionalities can be privileged during assessment processes, while being aware of the role of academics in creating a decolonised learning environment that makes this possible (Heleta, 2016; Vandeyar and Swart, 2019).

Boud (1995: 38) holds that '[s]tudents can ... escape from the effects of poor teaching, [but] they cannot ... escape the effects of poor assessment'. Challenges such as the massification of education, teaching students from diverse backgrounds and with various levels of proficiency in the language of teaching and learning (in our case, English), and increasingly limited resources, can easily

\footnotetext{
${ }^{1}$ This is decolonisation which aims to overturn the ongoing dominance of colonial ways of knowing and subjectivity. Mignolo (2007b: 156) explains that such dominance is one of the four interrelated domains of the "colonial matrix of power", namely "control of economy (land appropriation, exploitation of labor, control of natural resources); control of authority (institution, army); control of gender and sexuality (family, education) and control of subjectivity and knowledge (epistemology, education and formation of subjectivity).
} 
be used as excuses for using potentially watered-down assessments. While institutionally compliant, summative assessments might allow lecturers to cope with workloads in a changing higher education landscape, they might not meet the needs of students in developing their academic literacies ${ }^{2}$ or engaging in meaningful learning through assessment for learning. In this paper, we discuss assessments used in three courses with large groups of students. We aimed to find novel ways of not only dealing with the challenges outlined above, but of embracing them to develop new forms of assessment that were responsive to the realities of South African higher education and offer meaningful assessments that allowed for greater epistemic access ${ }^{3}$ and critical reflection for students from under-resourced backgrounds. The aim of this paper is to examine the affordances and challenges of group portfolio assessments in the context of massification, with increasing pressure to work actively towards decolonising South African classrooms. We do this by examining group portfolio assessments in three courses presented at two different South African universities (discussed in more detail in the Findings section of this paper). We argue that effective decolonial knowledge practices and deep critical engagement can be achieved by using group work portfolio tasks that align with assessment for learning principles.

\section{Literature review}

To frame our study, we consider the literature surrounding key themes that emerge from this study. These are the challenges and opportunities in the massification of higher education, decoloniality, group work, and assessment for learning.

\section{Massification in higher education: Challenges and opportunities}

Massification refers to the massive increase in enrolments at institutions of higher learning that began in the late $20^{\text {th }}$ century and is currently continuing and accelerating globally, especially in emerging economies (Mohamedbhai, 2014: 62). Mok and Neubauer (2016: 1) note that education systems all over the world have had to transform from elite higher education that only catered to small segments of the population, to mass education that caters for larger segments of citizens. In

\footnotetext{
${ }^{2}$ We draw on Kern's (2000) conception of literacy in a sociocognitive framework. Kern sees literacy as encompassing the following dimensions: linguistic (how language is used), cognitive (active thinking and problem solving) and sociocultural/psychological (acculturation into the specific conventions of particular discourse communities). Academic literacies, then, refers to acquiring increasing mastery, within academia and its specific disciplines, in using various modes appropriate to higher education to engage with the knowledges and problems posed by tertiary education studies.

${ }^{3}$ Muller (2014: 255) draws on Ryle and Winch in defining epistemic access as access that moves beyond perfunctory physical or formal access, and instead provides 'meaningful access to the "goods" of the university'. These 'goods' include both theoretical knowledge (or 'knowledge that') and practical or procedural knowledge (or 'knowledge how') (Muller, 2014: 262).
} 
developing countries, as Hornsby and Osman (2014: 712) highlight, 'higher education is viewed as an integral part in resolving social and economic inequalities present in societies', and thus massification has been linked to a social justice agenda in countries like South Africa.

Massification can take place at both national and institutional levels (Mohamedbhai, 2014: 67). At the national level, massification is associated with an increase of access to education for a broader segment of the population and is largely seen as positive for social and economic development. However, at an institutional level, massification is often associated with the overburdening of institutions when inadequate infrastructure is in place, when staff numbers have not increased at a similar pace with student numbers, and when government spending on higher learning has decreased in real terms on a yearly basis, as is the case in South Africa (Hornsby and Osman, 2014). Thus, institutional massification, while creating greater access, is regularly viewed as negative by various stakeholders, including teaching staff. The negative perceptions of teaching staff are based on increasing marking loads, an increasing number of students who require face-to-face consultation and individual feedback, and the need to incorporate ICTs or other innovative practices in their pedagogies, even when many might not have been adequately trained for these approaches (Loqo, 2017; Mohamedbhai, 2014). Many teaching staff members also find themselves having to discard forms of feedback, assessment and teaching that they had relied on when student numbers were lower and when funding was more readily available. Massification has had numerous negative effects, such as small group tutorials becoming less feasible (Sutherland, 2010) and a lack of time for detailed individual feedback on essays or assessments (Long, 2014; Lunt and Curran, 2010).

Mohamedbhai (2014: 59) notes that while increased student enrolment, often beyond the capacity of institutions, was a strategy to address inequality in African societies, this did not take into account the concerns of whether enrolled students would achieve 'equity of success', and there was inadequate consideration about how to ensure that the newly massified student body would be adequately served by existing university infrastructure. Research has shown that larger class sizes could lead to poorer outcomes for student learning, in that deep approaches to learning associated with critical thinking and engagement are focused on less and less by lecturers (Albertyn, et al., 2016; Hornsby and Osman, 2014). Large classes in higher education have been shown to affect students' attitudes, such as students showing 'poor levels of engagement with material, less commitment to courses and lower levels of motivation' (Hornsby and Osman, 2014: 713). Large classes are also counterproductive to classroom discussion and often lead to 'didactic teaching styles' (Hornsby and Osman, 2014: 713) that centre the lecturer in the learning process. This is especially problematic in light of the call voiced by decolonial thinkers to value and meaningfully incorporate the voices, knowledge, and perspectives of all students (Autar, 2017). However, despite these multiple concerns and challenges associated with massification and large class teaching, Hornsby and Osman (2014: 713) note that these environments are 'here to stay' and thus teaching staff need to find ways to adapt to large classes. 
South African higher education institutions (HEls) have seen increasing enrolment across the socioeconomic spectrum, coupled to calls to decolonise HEls epistemically, symbolically and in terms of staff and student demographics (Heleta, 2016). This has led to increased diversity in these institutions, as well as increasingly large class sizes that place pressure on teaching staff to innovate and to move away from established pedagogical and assessment methods. There are many opportunities inherent in massification in the South African context which can be employed by teaching staff to strengthen teaching and learning. Primarily, the increased diversity of the student body offers a greater range of lived experiences to draw from and allows for diverse perspectives and knowledges to be incorporated in teaching and learning (Gay, 2015). Additionally, the importance of group work is highlighted in these settings, especially in order for teaching staff to have manageable marking loads and for students to be able to receive more regular feedback (Freeman, 1995).

Mohamedbhai (2014: 81) cautions that institutions undergoing massification need to be guided by certain principles, including that they must 'take all necessary measures for the adequate success of all the enrolled students, especially those who experience difficulties in adapting to the higher education environment'; in addition, they must 'never compromise on quality' and 'ensure that their teaching and research are relevant to their respective country's needs'. These principles were paramount in our decisions to use group assessments and reflective components in our courses, as this allowed peer learning to become central, and the knowledges, literacies, and critical reflections of all students to be increasingly valued in their assessments.

\section{Decoloniality in the higher education context}

Because of the role of universities in producing and transmitting authoritative knowledge, they are implicated in maintaining two arms of the colonial power matrix (Mignolo, 2007b), namely institutional authority and epistemological domination. Our argument focuses on epistemological coloniality, which still overwhelmingly shapes university curricula and academic practices in South Africa, though challenges to this dominance both within and outside of academia (such as the 20152018 Fees Must Fall protests ${ }^{4}$ ) are becoming more common. Decolonial critique aims to destabilise the ideologies of universality and objectivity underpinning many western knowledge discourses, including those of the university, and to look beyond these discourses to open space for other epistemologies. This active opening of space, which Nakata, et al. (2012: 124) call 'decolonial

\footnotetext{
${ }^{4}$ The Fees Must Fall protests were large protests by students and supporters of the cause at a number of South African higher education institutions. The protests challenged how the colonial aspects of these institutions, symbolised by relics of colonialism like the statue of Cecil John Rhodes at the University of Cape Town, and also highlighted how universities excluded students in multiple ways, including financially, epistemically and linguistically. A key demand from protesters was that higher education should be tuition free in South Africa. For more on this topic, see Langa (2017).
} 
knowledge-making', can be understood as knowledge making 'that reasserts and draws in concepts and meanings from indigenous knowledge and systems of thought and experience of the colonial'. Such knowledge-making is not easy, because indigenous knowledge traditions persist in complex entangled relationship with colonial knowledges (Hountondji, 1996; Smith, 2013). We argue that the practical work of epistemic decolonisation in university classrooms therefore must begin with bringing forward, as Nakata, et al. (2012: 126) phrase it, 'contemporary Indigenous lifeworlds ... for analysis and innovative engagement and production'. Within the constraints caused by massification and by global distributions of social and cultural capital, in which a traditional western university education is desired as a ticket out of poverty, our work in the three courses we describe aims to begin this kind of innovative engagement with our students' varied knowledges and experiences.

\section{Group work}

The courses we discuss all used collective learning, in which peers work together interdependently towards a shared goal (Topping, 2005). Group work fundamentally changes classroom dynamics, perhaps most importantly in terms of addressing problems related to growing lecturer-student ratios due to massification, in that peers take on some of the roles traditionally assigned to lecturers. Students have more opportunities to respond to others' work and to receive individualised feedback to their own work, and there are more opportunities for immediate formative feedback and error correction (Cohen and Lotan, 2014). Students rely on each others' strengths to collaborate on work, rather than solely relying on the lecturer's input. Group work therefore builds on the strengths of individuals, both lecturers and students (Topping, 2005), and can promote learning that is active, deep, experiential, collaborative and cooperative (Davies, 2009; Topping, 2005). Group work can also be used as authentic assessment, as working collaboratively with colleagues it is part of many professions (Davies, 2009). In terms of assessment for learning, group assessment is 'extremely valuable in helping students interpret criteria and encourages the development of students' metacognition (Brown, 2005: 88). Evidence also suggests that group work has parallel social and emotional benefits: students' motivation and enjoyment increase (Fellenz, 2006; Poort, et al., 2019), and even brief exposure to group work can enhance students' self-esteem and psychological health (Cohen and Lotan, 2014; Topping, 2005). Working in groups can foster 'social membership' (Watkins, 2004 in Davies, 2009: 564) in the learning environment and an ethos at education institutions characterised by helping and caring (Topping, 2005).

In culturally diverse classrooms, however, where students have different levels of access to dominant languages and cultural modes of communication, group work negotiations are complex. According to Volet and Ang (2012: 34), culturally dissimilar groups in universities where English is the language of teaching and learning do not spontaneously mix, since crossing cultural barriers 'requires deliberate, mentally demanding effort'. Group work can provide a structure for consciously assisting students in crossing these barriers. Furthermore, students can perform their cultural 
identities more consciously and purposefully in group situations, adopting discourses that reinforce their own culture, language, and identity (Melles, 2004). Shin (2006) warns that group work pedagogies are often premised on Anglo-Saxon notions of being communicative, in contrast to indigenous ontologies and ethics that value other forms of group interaction (she mentions Vietnamese notions of group harmony). In contexts where English is the language of teaching and learning, students from non-English speaking backgrounds are not as active in group work discussions as first-language English students (Davies, 2009; Volet and Ang, 2012). On the other hand, group members also capitalise on each-others' access to dominant discourses, with written work, for example, often done by the student with the greatest fluency in English (Davies, 2009). A meta-analysis of over 100 studies on group diversity and performance shows that diversity is associated with higher levels of conflict, but also enhances several aspects of performance, including creativity, communication, and satisfaction (Stahl, et al., 2010).

In the context of massification, however, group work is challenging. First, significant investments of time and resources are required initially and during group work. Project design must suit instructional goals, institutional context, and population (Bourner, et al., 2001; Topping, 2005). While students' learning increases in depth, less content can be covered, as instructional pace is now set by group work, rather than lecturer presentation (Hammar Chiriac, 2014; LaBeouf, et al., 2016). Students require training in their roles, otherwise group members mostly work alone, and their peer mentoring strategies tend to remain underdeveloped (Topping, 2005). Ongoing monitoring of peer interactions and students' work is needed for accuracy and effectiveness (Cohen and Lotan, 2014; Topping, 2005). Culturally diverse groups also invest extra time and effort to communicate across different perspectives (Poort, et al., 2019). These investments of time and work may be prohibitive under the pressured conditions created by massification.

Secondly, problematic group interactions have practical and ethical implications. If groups are homogenous, for example, with all members of the group of the same ability, 'meta-ignorance' may result, where group members are unable to recognise and correct gaps in knowledge, literacies or understanding if these gaps are shared by others in the group (Topping, 2005). Alternatively, if groups are heterogenous in terms of ability and motivation, problems include 'free riding,' when less motivated group members leave the work to their fellows, and the corresponding 'sucker effect,' when more engaged members refuse to work because they do not want to be 'suckers' (see, for example, Bourner, et al., 2001). When group work is assessed, the question of fairness is most urgent; projects work best when assessments reward both individual accountability and group goals (Davies, 2009; Fellenz, 2006; Topping, 2005). It is important to mitigate these risks and ensure that the strengths of group work are harnessed when designing group projects. For our courses, we were guided by assessment for learning principles to ensure that our group assessments encouraged active engagement and critical reflection during the learning process. 


\section{Assessment for learning}

The main argument of assessment for learning is that all assessment should support the advancement of learning in particular disciplines (Carless, 2015) and should allow students to take control of their learning and develop the capacity to monitor the quality of their own work. The 'double duty' of assessment (Boud, 2000) refers to assessment that functions as formative assessment for life-long learning and assessment that is summative that can contribute towards the process of certification. This double duty often appears onerous, especially in research-led universities where student numbers and research pressure severely limit the time lecturers have. There is an ongoing tension between using assessment to stimulate student learning and using it for accountability purposes by institutions to measure student achievement. The task design and group portfolio intervention in the three learning contexts described in this paper demonstrate attempts to reduce the dominance of traditional disciplinary exams in a context of assessment of learning and large undergraduate classes. We are aware that we need to combine an understanding of how students are progressing (assessment of learning) with creating learning opportunities to promote the right kind of learning (Carless, 2015: 89).

Gibbs (2019) argues that the onus is on teaching staff to create conditions under which assessment supports learning rather than merely measuring what they have already accomplished. These theorists draw on Bloxham and Boyd (2007) who outline a number of assessments for learning principles which involve a combination of formative and summative assessment activities. Key amongst these are that 1 ) tasks should be challenging and require students to integrate knowledge they have learned on the course with their experiences and knowledge from other contexts, 2) tasks need to be fit for purpose and align with intended learning outcomes, and 3) assessment requirements should be made visible to students in order for students to engage actively and critically. Similarly, Carless (2015) has developed a Learning Oriented Assessment model in recognition of the significant role assessment plays in framing learning. He argues that the two key elements of this model are 1) to develop students' capacity to evaluate their own practices and 2) for them to engage productively with feedback. Recent literature on feedback practices (Winstone and Carless, 2020: 9) challenges the old feedback paradigm of merely providing information to students, to a new design-focused paradigm that optimises the effects of feedback on student learning. Students play a central role in their own development as 'assessment designs encourage the uptake of feedback' (Winstone and Carless, 2020: 12) using a variety of processes.

The purpose of varied teaching and learning activities is to transform students' learning through the use of incremental tasks, self and peer feedback, and using exemplars and rubrics, among other learning-oriented strategies. As course designers, we were committed to maintaining the integrity of these assessment for learning principles while addressing the contextual constraints of large student numbers and uneven levels of student preparedness for university studies. 
Evidence-based portfolios are one instrument that can be used to facilitate the assessment of varied teaching and learning activities. There is consensus in the literature on portfolio tasks that they are more likely to demonstrate achievement of a range of skills and capabilities than other forms of objective and productive assessment tasks. Winstone and Nash (2019: 133) found that portfolios where there are 'action points' for implementing feedback can promote reflection, independence and 'feedback-seeking behaviour'. This is contingent on students understanding the terminology and forms of literacy used in rubrics and feedback schedules and the importance of integrating evidence and its relevance to the intended learning outcomes. We decided to use evidence-based portfolios in all of the courses discussed due to these affordances and to address the dual purposes of formative and summative assessment (cf. Boud, 2000).

\section{Method}

This article offers an example of socially responsible research with regard to effectively and fairly assessing large classes within the field of higher education. Reeves, et al. (2005: 100-101) recommend a design-based research approach as 'a particularly appropriate approach to socially responsible inquiry'. Design-based research is a form of participatory action research in which we, as researchers and lecturers simultaneously, reflect individually and as a team on the pedagogy we are using. In other words, we are examining 'what we did and why we did it' (Green, et al., 2010: 262), so as to share emerging knowledge and to continually deepen our critical reflection on our practice. Design-based research 'posits synergistic relationships among researching, designing and engineering' of courses, and is not only based on theory, but also conducted so as to generate theory (Wang and Hannafin, 2005). It is a pragmatic, grounded, systematic, yet flexible methodology that works toward improved educational practices by means of 'iterative analysis, design, development, and implementation, based on collaboration among researchers and practitioners in real-world settings' (Wang and Hannafin, 2005). Despite similarities with action research, design research attempts to find solutions for classroom challenges by considering design knowledge and principles which others may apply in their own courses (Reeves, et al., 2005: 107). This article is the first step towards a larger project guided by design-based research and is guided by the principles above.

In the current study, we use the design-based approach to describe the pedagogical and conceptual underpinnings of three courses that aimed to responsibly assess large classes, both formatively and summatively. We discuss the affordances and challenges of each of the assessment approaches used in these three courses. We conclude by describing the evolving, co-constructed conceptualisation of learning as knowledge creation of our community of practice (Hong and Sullivan, 2009), thus moving theory forward (cf. Reeves, et al., 2005) in relation to the innovative assessment practices in our respective courses.

We believe the inquiry into teaching and learning to be of great value to ultimately enhance the assessment practices in our respective contexts. We also believe similar courses could benefit 
from these reflections, as we as co-researchers have benefited from reflecting on the assessment practices in each others' courses. The next research cycle will involve a dialogue and collaboration with our students as part of a process of mutual knowledge building.

\section{Findings}

Three courses taught at two South African universities, and the assessments used in these courses, are explored here. Both universities are traditional public universities of high standing. Both were established towards the end of the nineteenth century and have had to adapt drastically due to the massification of higher education.

Though all three assessment methods relied on some type of portfolio activity as well as group work, how the courses approached and executed their assessments differed in significant ways. This section starts with a brief outline of the various courses, after which the affordances and limitations of the three assessment approaches are critically discussed. Each discussion clarifies how that course exemplifies particular principles of assessment for learning.

\section{Course 1: New literacies for high school teachers}

\section{Outline}

The first course is a general literacy course presented to first-year education students studying to become high school teachers. Approximately 400 students take this course each year over three terms (21 weeks), with three to four staff members teaching groups of approximately130 students per class. Drawing on sociocultural theories of literacy (Mckinley, 2015), students are guided towards thinking theoretically about the literacies that they need for their own studies and for teaching in their chosen subject disciplines. They also analyse and evaluate the links between language, literacy, culture and identity in the South African context, by understanding basic concepts pertaining to literacy studies.

The final assignment of the course is of particular relevance to the current study. This assignment aims to consolidate students' knowledge of New Literacy Studies (NLS), a sociocultural theory of literacy where social contexts and literacies interact and inform each other (Gee, 2008; Lea and Street, 1998; Lillis, 2003). The assignment asks students to link this theory to situated literacies in their different social contexts, considering a variety of discourses and texts. Students submit four portfolio activities as well as a self-reflection task, each being the focus and end-product of one week's classes. Three students with the same teaching subject (mathematics, physical sciences, life sciences, English, information technology, history, isiZulu or social sciences) work together as a group. Each group has a reading pack in their shared subject, containing an academic article, textbook extract, exam paper, and extract of a lesson transcript. All portfolio activities centre around this reading pack and the types of situated literacies present in the texts. Students receive a group mark for the four portfolio activities, and an individual mark for the self-reflection tasks. The portfolio 
activities aim to guide students to understand the consequences of the NLS theory for subjectspecific literacies, to reflect on their own subject-specific literacies as students and as studentteachers, and to develop reading and writing strategies for learning in specific subjects, genres and learning communities.

Portfolio activities are relatively short so that groups can complete these activities in the 1.5 hours per week set aside for working on them, while the lecturer is present to answer questions and facilitate the activities. Figure 1 indicates the topics of the portfolio activities.

\section{The Triads Project}

Over the course of block 4, you will work in groups of 3 with other students taking the same major teaching subject as you, to explore the situated literacies required by this subject.

- You will work with THREE texts for your subject discipline - a textbook extract, an academic article, an assessment, or (for languages and History) a primary text.

- You will submit your portfolio of tasks 1-4 as a group, and then your reflection task 5 individually.

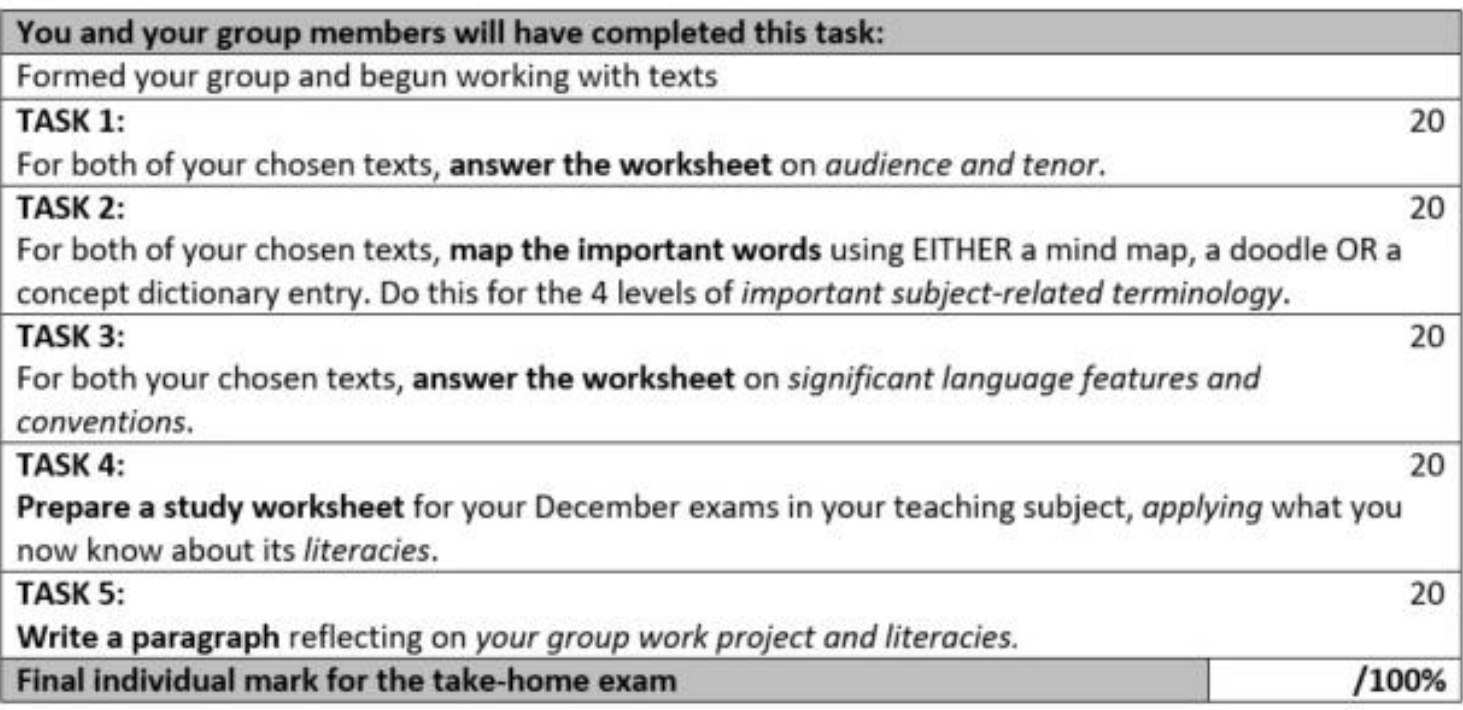

Figure 1: Outline of final 7 weeks of the New Literacies for High School Teachers course

\section{Affordances and limitations}

The portfolio functions as a summative assessment of a compulsory course that provides foundational concepts in the curriculum. We initially designed the project as group work to help reduce the marking load of a team of four lecturers who were responsible for marking over 400 students' work. However, it also has significant formative aspects. Because the groups do the tasks in class, they can receive immediate verbal feedback from the lecturer, even in a class of 130 students. 
In addition, through the design of the tasks, which require students to reflect together on the situated subject-specific literacies they are developing at university, they also receive ongoing peer feedback. In terms of the principles of assessment for learning, the project tasks were challenging, and required students to integrate knowledge from their subject courses and personal experience with the literacy theory content. The ongoing emphasis on reflection, which culminates in the final individual reflection task, led students to focus not only on the course content but also their processes of learning, leading to metacognitive awareness (Cross, 2010). We found that completing the challenging and complex tasks with classmates enabled students to recognise the various literacies that they required in academic work. The portfolios also allowed for incremental learning, where students were required to incorporate concepts and skills from previous lessons and tasks into each new task (Bloxham and Boyd, 2007). This process aimed to make tangible how literacies develop, change, and grow, while metacognitively students could see themselves as active participants in the literacy practices that we discussed in the theory sections of the course.

The group work nature of the portfolio assessment also had particular affordances. Throughout the design process, our aim was to invite the students' knowledges into the classroom (Gay, 2015), and to practically exemplify how they are reservoirs of knowledge about out-of-school lives and cultures that could enhance their understanding of situated literacies and benefit them in the academic space. The extensive time set aside in class for group work changed the dynamics of the classroom, freeing students to bring their repertoires into play. As lecturers moved around the group practical sessions, we heard many students use their home languages to discuss challenging concepts or tasks, rather than feeling obliged to use English. We believe that students showing pride in their home languages, and using these as vehicles for learning, is a positive step towards a decolonised classroom (cf. Melles, 2004). Students were also encouraged to use examples of their own literacy practices and reflect on these practices meaningfully as part of their formal assessments. The portfolio tasks offered an opportunity for students to draw on multiple literacies and cultural repertoires, and to consciously examine these as part of formal academic requirements.

The group work portfolio project offered many opportunities to meet the needs of assessment for learning and to offer individual and group formative assessment. Marking time was also reduced for the teaching staff. However, several limitations emerged. We spent time on problems arising from the group nature of the assessment, including internal group conflict, individual group members missing deadlines and derailing group work, and at times members disagreeing on how best to answer the tasks. There were also complaints of free-riding from several groups.

This portfolio assessment was designed with the intention of building oral formative feedback, and students' engagement with this feedback, into the weekly tasks. This enabled the limited teaching staff to work with a very large class. However, this weekly oral feedback was arguably not sufficient to constitute effective assessment for learning. The fact that we only formally assessed these group tasks at the end of the teaching block in the form of a take-home exam meant that we 
could not monitor some misunderstandings that arose throughout the term, especially for students who did not attend the practicals or who did not ask questions during these sessions, thus limiting effective formative feedback. In future iterations of the course, more extended use of exemplars (Carless, 2015) could be built into the lecture discussion of literacy practices.

A final limitation of our design was that the student groups were self-selected. As has been noted in other studies (Volet and Ang, 2012), students did not spontaneously mix across cultural backgrounds and levels of academic literacy. Many groups were thus homogenous culturally, racially and in terms of educational background. As a result, the affordances of learning from students from other backgrounds were not optimised. Further thinking is required about how to support students to make the deliberate effort needed to communicate across cultural and other differences without taking away students' agency.

\section{Course 2: Integrating assessment literacy into an undergraduate teacher education course}

\section{Outline}

The critical role of assessment for learning emerges strongly in the fourth-year course on classroom assessment for B. Ed students. The aim of the course is to highlight the tension between using assessment to promote student learning and using assessment for measurement and accountability purposes in schools. The course, which has approximately 520 students, draws on a range of theoretical concepts that inform how student teachers use, manage, adapt, and create assessments. Students build a critical understanding of key assessment concepts and are introduced to principles and practices of high-quality assessment tasks, rubrics, and feedback. The focus on assessment literacy enhances their awareness of assessment issues in their dual role as Education students and as pre-service teachers.

Because of the large class size, in 2018, students were placed in groups of four or five in tutorials where they were provided with a portfolio workbook containing a range of reading and writing activities. They were required to engage in weekly tutorial activities which would form part of their group portfolios submitted at the end of the course. Self and peer assessment activities were embedded in the tutorial tasks, and students were expected to draw on and integrate ideas from lectures, course texts and their own assessment experiences. They were encouraged to engage critically with the assessment concepts and show evidence of group participation for which they were assessed similar to processes to be described in Course 3. The following topics were covered in the tutorial programme: purposes of assessment in the curriculum; reliability, validity, and fairness in assessment; designing fit for purpose assessment tasks; formulating assessment criteria and feedback; the role of emotion in assessment; error analysis in assessment and implementing learning-oriented feedback practices. To compile their final group portfolio, students were required 
to select and reflect individually on the tutorial tasks that best represented their learning on the course.

\section{Affordances and limitations}

The group portfolio task was continued in 2019 and 2020 and has also become an established part of the third year B. Ed curriculum. This introduction to a 'learning-oriented assessment' paradigm (Carless, 2015) is particularly pertinent for future teachers who require exposure to a transparent approach to assessment criteria and standards. The inevitable challenges with group work activities have come to the fore in this intervention as described in Course 1, and in the course lecturers and tutors are constantly grappling with how to promote self and peer accountability. Students were initially reluctant to participate in peer feedback but became more open by the end of the tutorial programme as the learning benefits became more evident. Furthermore, the validation of these assessment processes in the portfolio assessment grading structure motivated them to participate in new ways of working with assessment for learning concepts and practices.

The implementation of these portfolio tasks in an assessment course for Education students has highlighted the importance of integrating real course tasks into the course rather than add-on activities at the end of the learning process. Preliminary findings and performance on the portfolio have shown that students are more involved in reflecting on assessment practices. By working on these tasks collectively in their assigned tutorial groups, students have built up a shared understanding and language of assessment, which is the basis of the course content and which models dialogic processes of engaging with the course concepts. The multi-layered modelling for students of doing assessment differently has hopefully given them tools for thinking about the transformative possibilities of implementing assessments in their future classrooms.

\section{Course 3: Academic literacy for economic and management sciences students}

\section{Outline}

The third course is a year-long academic literacy course presented to 270 foundation programme first-year students (divided into five classes) in the economic and management sciences. The project that students work towards in the final half (or 14 weeks) of the year is of particular interest. This assessment is shared by three subjects, namely the academic literacy subject, a business management subject, and a statistics subject. In the final semester of their first year, students engage in a community project where groups of five students need to identify a need at an Early Childhood Development (ECD) centre in a South African township area. They then need to address this need and write a report on this process using all the knowledge, abilities and competencies gained during the year-long academic literacy course, as well as the other two participating courses. Students are set weekly smaller tasks and goals which all lead up to them writing up the process in the final research report. The assessment relies heavily on process writing and peer feedback. 
This foundation level course originally started with small classes of approximately 20 students each. At that point, in-depth individual continuous assessment of each student was possible. Since then, student numbers per class tripled to close to 60 students per class (in line with Mohamedbai's [2014] discussion on the massification of education in emerging economies), as did lecturer workload in general with a drastically increased student-lecturer ratio. Consequently, assessments became watered down to allow lecturers to cope with the workload. Students became less interested in the course as assessments became less relevant and demanding. The team responsible for this course felt that it was losing its impact, and gradually started working towards developing this rather ambitious project.

\section{Affordances and limitations}

As was the case with Courses 1 and 2, this project took the form of a portfolio assessment, with formative assessment tasks building towards a summative final product. This format allowed for a medium in which students could integrate and demonstrate application of everything they had learned over a year-long period, thus addressing the assessment for learning principles of considering both content and the process of learning (Boud, 2000). The assessment employed weekly small goals and continuous drafting, with formal formative assessment taking place throughout the process. This enabled students to engage with various aspects of the project while receiving feedback from peers within their own group and other groups, so as to continuously improve their writing. Training students in the feedback process helped to mitigate the negative effects of large class sizes and increased students' awareness of their own writing processes and those of other students. The peer learning that took place between groups (as each group was required to give in-depth feedback on the drafts of other groups at various stages of the project) capitalised on advantages of group work such as providing regular immediate formative feedback within a collaborative and cooperative environment.

Group work was a significant focus in this project. Each group member was assigned a specific area of responsibility, in which they had to manage the participation of the other group members. These areas included conducting research, accurate referencing and editing, group cohesion and general project administration. This made it possible for students to choose areas in which they considered themselves as being strong, and mentoring peers in those areas to ensure a good final product, thus effectively participating in collective learning (cf. Topping, 2005). In addition to students being allowed to specialise in the areas they saw themselves as being the strongest in, the perspectives and resources brought by students from different backgrounds also proved immensely valuable in this project. Some students grew up in townships, and they could help students who felt uncomfortable with the location of the ECD to navigate the new surroundings with more confidence. Other students came with resources of connections or confidence that assisted them in finding ways of addressing the need at the ECD. Many students from non-dominant communities were able to 
display strengths (including multilingualism and community cultural wealth) that are not traditionally valued in the academic domain, but that benefited their groups significantly.

Students within each group were held accountable to one another as they assessed one another's participation in the group work at the end of the project. Students were encouraged to give each other $100 \%$ if group members had contributed as per agreement at the beginning of the group project. This would mean that each student would receive the full mark awarded by the lecturer. However, if students did not contribute as had been agreed upon, they would be marked down. For example, a lecturer might award a group 60\% for an assignment. If other group members feel that a specific member only contributed $70 \%$ of the work that had been agreed upon, that group member would receive a final mark of $42 \%(0,7 \times 60=42)$. Despite initial fears from lecturers that this type of assessment would lead to many complaints, students almost unanimously accepted the marks they received from group members. Due to its success, this system has since been implemented in other group projects. Increasing engagement by means of this measure (and thus effectively preventing 'free-riding') contributed towards many of the emotional benefits of group work, including increased motivation and enjoyment, increased feelings of self-worth, and improved social membership. The authenticity of the assignment also enabled enhanced approaches to deep learning, and, we believe, towards the transferability of skills.

There were however some limitations to this project. Firstly, considering its scale, unequal commitment from stakeholders (in particular participating lecturers) led to delays and frustration for all participating subjects. Furthermore, in cases where communication between lecturers was not constant and clear, confusion was caused amongst students. Although the format of this assessment relieved some marking pressure from lecturers, it added administrative pressures, and led to more student consultations. The latter, however, we believe to be a good thing, as this showed that students were truly engaged with the project. This project worked well in a context where each lecturer was responsible for three classes of 50 students each. Higher student numbers, however, would require additional teaching and administrative assistance, which is often difficult to obtain in a resource-poor higher education environment. Despite these limitations, this project led to outcomes that few stakeholders believed would be possible, and it has become an integral part of the curriculum.

\section{Discussion}

\section{The role of assessment for learning principles and practices in the three courses}

Although the potential of formative assessment for enhancing student learning is now wellrecognised and can play a significant role in the enhancement of learning (e.g. Black and Wiliam, 1998; Carless, 2015), major obstacles to implementation remain. The institutional culture of accountability and assessment of learning through tests and exams often restrict lecturers' capacity to integrate formative assessment practices systematically into their curricula. As mentioned in all 
three courses, despite our willingness to try out new assessment strategies to promote student learning, time, space, and resource constraints often made it difficult to sustain an even balance between formative and summative assessment. Despite these obstacles, findings from all three courses have shown that students became more involved in judging their own and one another's work against standards rather than relying solely on the lecturer. The course lecturers wished to model for students, by means of the portfolios, a move away from endpoint summative types of assessment to 'responsibility-sharing' activities (Sambell and Sambell, 2019) which empower students to make informed judgements about their own work.

Feedback has played a key role in all three courses in helping students develop evaluative judgment. In Course 1, students received prompt and ongoing feedback from their peers and tutors. Analyses of the portfolios indicated the role of peer review processes in enhancing their writing confidence and proficiency. In Course 2, students drew extensively on the feedback they received from peers and tutors to challenge their assumptions about concepts like assessment criteria as they interrogated the top-down formulation of assessment tasks and rubrics. In Course 3, students were trained to engage in the feedback process and accumulate economic and management sciences concepts through peer interactions. They learnt to place high value on formative feedback processes.

It would be remiss not to mention that group work portfolios do pose specific challenges. The main limitation is probably the inevitable conflict that arises from this mode of learning. Students were frustrated by members missing deadlines as well as 'free-riding' (as seen in Course 1). A solution to this limitation could be the approach followed in Course 3, where each student was assigned an area of responsibility, and where students assessed each other on the extent to which each member participated, as had been agreed upon by the group. This measure would work towards accountability in the 'responsibility-sharing' activities referred to by Sambell and Sambell (2019).

Despite real challenges that need careful and continuous thought in the planning of subsequent assessment cycles, the portfolios have provided a vehicle for students in our three courses to develop metacognitive awareness of their thinking processes and to deepen their sense of control over their writing. Metacognitive awareness enables students to identify their own learning strengths and strategies and has been linked to increased reading comprehension as well as academic achievement (Jaleel, 2016; Young and Fry, 2008). As the designers of these courses, we have a heightened awareness of the affordances and constraints of integrating group work portfolio assessments into our courses. This ongoing process of reflection has enabled us to plan for assessment changes in our courses so that students can derive educational benefits from their engagement with portfolios.

\section{Decoloniality}

The group work projects discussed in this paper begin to open university spaces to other 'loci of enunciation' (Mignolo, 2007a: 460), in two distinct but related ways. These three assessment 
projects, in their group-work nature and in their use of assessment for learning, have potential to unsettle the coloniality of the HE spaces in which they take place. Firstly, in all three courses conscious attempts were made to draw on students' 'social and cultural backgrounds and positionalities' (McKinley, 2015: 186). We believe that this stance towards learning actively contributed to our students becoming members of the academic tribe; in other words, our students became insiders in the various discourses they engaged in by drawing on their existing strengths and those of other students, rather than being made to feel alienated from their primary and previously acquired discourses. Course 1 probably did this most explicitly, actively drawing students' attention to the strengths they bring with them from previously acquired discourses and different backgrounds and requiring them to explore these as valid forms of knowledge-making. In Course 3, students from mixed backgrounds work together, recognising and drawing on each other's strengths and perspectives, while contributing positively to ECDs in a township community and implementing knowledge and skills towards the greater social good. More work could be done to make these principles explicit to students and integrating discussions into classes of the strength of diverse discourses. This would work towards empowering students to gain epistemic access to new discourses (thus becoming insiders to these discourses) without devaluing or negating other discourses which could (possibly unconsciously) push students to become outsiders of their existing discourse communities.

Secondly, Course 3 foregrounds one of the principles of assessment for learning discussed earlier in this article, namely making assessment criteria visible to students so that they can engage with them actively and critically. Such a practice gives students access not only to how their learning will be assessed, but also to the discourse of assessment itself. This enables an understanding of the particular kinds of rational thought and rhetorical use of language that are valued in dominant forms of academic literacy which typically reflect Western values and knowledges and disparage other ways of thinking and being. Powerful aspects of the hidden curriculum (Giroux, 2001) of HE are thus opened to discussion and critique by students who come from different cultural and class backgrounds. Part of our iterative design practice must be to actively further such decolonial practices in class, and to foreground our assessment practices on this ongoing critique.

\section{Conclusion}

With this paper, we aimed to respond to the demands of the current higher education context and the need to decolonise the curriculum (e.g., Behari-Leak, 2019; Vorster and Quinn, 2017), by indicating how one form of assessment has the potential of effectively addressing aspects of both of these. This article has shown that by using portfolio-based group work assignments, pedagogically sound assessment can be approached in a systematic manner to purposefully address the challenges faced in the South African higher education landscape. Most notable amongst these challenges are those of massification, needing to decolonise the curriculum, as well as creating assessments that 
contribute to learning in innovative ways, rather than using 'easier to mark' high stakes methods of assessing acquired knowledge. In our three contexts, portfolios have emerged as rich assessment tools that allow students to engage with content both critically and reflectively, and for metacognitive awareness (Cross, 2010) to take place. Importantly, the affordances of group work portfolios (many of which were unanticipated when we started our respective projects) are well-suited to the massified South African higher education context. This is because they allow for modes of learning such as peer assessment, for collaboration through the social construction of knowledge, and for recognising and drawing on the strengths of all students, including those who are epistemically and symbolically excluded from the dominant coloniality in many HEls. Some of the negative effects of massification of education were countered effectively due to the use of peer learning and group work, as well as the format of various smaller assessments leading to a larger assessment. All three courses succeeded in offering confidence-building activities and opportunities for conceptual engagement though intensive writing and reading activities.

This mode of assessment is not without challenges. Assignments following this route must be meticulously planned well ahead of the commencement of the assessment process. Furthermore, mediation as well as lecturer involvement are crucial for effective group work. This, in turn, requires resources, as well as commitment and enthusiasm from participating lecturers. Without these challenges being acknowledged and carefully planned for, this method of assessment is likely to prove unsustainable.

There is still much scope for research in this field. Future research on these projects will include collecting empirical data on how different students engage with groupwork portfolio assessments. In addition, more consideration is needed for how regular feedback can be included in weekly tasks without making the process excessively laborious for lecturers, e.g., through using a variety of sustainable feedback modes and enhancing students' capacity for self-evaluation. Future research will also further examine how group work can be better designed and facilitated more purposefully. However, if these can be planned for effectively, the use of portfolio-based group assignments has the potential of shifting ground by being one of the most sustainable, ethical, and responsible routes towards assessment in the current higher education climate.

\section{Author Biographies}

Ilse Fouche is a senior lecturer at the Wits School of Education Division of Languages, Literacies and Literatures. Her research interests lie in creating effective discipline-embedded academic literacy interventions, optimising language learning by means of blended learning strategies, and integrating socially embedded community engagement elements into university curricula. 
Grant Andrews is a senior lecturer at the Wits School of Education Division of Languages, Literacies and Literatures. He teaches courses on critical literacy, media studies and English literature. His research focuses on gender and sexuality in literature, film, and education.

Laura Dison is a senior lecturer in the Curriculum Division at the Wits School of Education and Assistant Dean for Teaching and Learning, Faculty of Humanities. She is the Co-coordinator of the Post Graduate Diploma in Education (Higher Education) and is Academic Coordinator of the School of Education Writing Centre.

Maria Prozesky is a senior lecturer at the Wits School of Education Division of Languages, Literacies and Literatures. Her main research interests are literature in the classroom, critical digital literacy, and decolonisation. She supervises postgraduate students working on academic literacy, culturally sustaining pedagogy, and decolonisation of the literature curriculum.

\section{References}

Albertyn, R.M., Machika, P. \& Troskie-de Bruin, C. 2016. Towards responsible massification: Some pointers for supporting lecturers. Africa Education Review, 13(3-4): 49-64.

Amineh, R.J. \& Asl, H.D. 2015. Review of constructivism and social constructivism. Journal of Social Sciences, Literature and Languages, 1(1): 9-16.

Au, W. 2009. Decolonizing the classroom. Rethinking Multicultural Education: 247-254.

Behari-Leak, K. 2019. decolonial turns, postcolonial shifts, and cultural connections: Are we there yet? English Academy Review, 36(1): 58-68.

Black, P. \& Wiliam, D. 1998. Assessment and classroom learning. Assessment in Education, 5(1): 7 74.

Bloxham, S. \& Boyd, P. 2007. Developing Effective Assessment in Higher Education: A Practical Guide. London: McGraw-Hill Education.

Boud, D. 1995. Enhancing Learning through Self-Assessment. London: Routledge Falmer.

Boud, D. 2000. Sustainable assessment: rethinking assessment for the learning society. Studies in Continuing Education, 22(2): 151-167.

Bourner, J., Hughes, M. \& Bourner, T. 2001. First-year undergraduate experiences of group project work. Assessment \& Evaluation in Higher Education, 26(1): 19-39.

Carless, D. 2015. Excellence in University Assessment: Learning from Award-winning Practice. London: Routledge.

Cohen, E.G. \& Lotan, R.A. 2014. Designing groupwork: strategies for the heterogeneous classroom. $3^{\text {rd }}$ ed. New York: Teachers College Press.

Cross, J. 2010. Raising L2 listeners' metacognitive awareness: A sociocultural theory perspective. Language Awareness, 19(4): 281-297. 
Davies, W.M. 2009. Groupwork as a form of assessment: Common problems and recommended solutions. Higher Education, 58(4): 563-584.

Fellenz, M.R. 2006. Toward fairness in assessing student groupwork: A protocol for peer evaluation of individual contributions. Journal of Management Education, 30(4): 570-591.

Gay, G. 2015. The what, why, and how of culturally responsive teaching: International mandates, challenges, and opportunities. Multicultural Education Review, 7(3): 123-139.

Gee, J. 2008. Social Linguistics and Literacies. Abingdon: Routledge.

Gibbs, G. 2019. Innovative assessment in higher education: A handbook for academic practitioners. In Bryan, C. and Clegg, K. (eds.) Innovative Assessment in Higher Education: A Handbook for Academic Practitioners. $2^{\text {nd }}$ ed. New York: Routledge, 22-35.

Giroux, H.A. 2001. Theory and Resistance in Education: Towards a Pedagogy for the Opposition. Westport: Greenwood Publishing Group.

Green, N.C., Edwards, H., Wolodko, B., Stewart, C., Brooks, M. \& Littledyke, R. 2010. Reconceptualising higher education pedagogy in online learning. Distance Education, 31(3): 257-273.

Hammar Chiriac, E. 2014. Group work as an incentive for learning-students' experiences of group work. Frontiers in Psychology, 5:558.

Heleta, S. 2016. Decolonisation of higher education: Dismantling epistemic violence and Eurocentrism in South Africa. Transformation in Higher Education, 1(1): 1-8.

Hong, H.-Y. \& Sullivan, F.R. 2009. Towards an idea-centered, principle-based design approach to support learning as knowledge creation. Educational Technology Research and Development, 57(5): 613.

Hornsby, D.J. \& Osman, R. 2014. Massification in higher education: Large classes and student learning. Higher Education, 67(6): 711-719.

Hountondji, P.J. 1996. African Philosophy: Myth and Reality. Bloomington: Indiana University Press.

Jaleel, S. 2016. A study on the metacognitive awareness of secondary school students. Universal Journal of Educational Research, 4(1):165-172.

Kern, R. 2000. Literacy and Language Teaching. Oxford: Oxford University Press.

LaBeouf, J.P., Griffith, J.C. \& Roberts, D.L. 2016. Faculty and student issues with group work: What is problematic with college group assignments and why? Journal of Education and Human Development, 5(1):13.

Langa, M. (ed.). 2017. \#Hashtag: An Analysis of the \#FeesMustFall Movement at South African Universities. Johannesburg: Centre for the Study of Violence and Reconciliation.

Lea, M.R. \& Street, B.V. 1998. Student writing in higher education: An academic literacies approach. Studies in Higher Education, 23(2): 157-172.

Leeds-Hurwitz, W. 2009. Social construction of reality. Encyclopedia of Communication Theory, 2:891-894. 
Lillis, T. 2003. Student writing as' Academic Literacies': Drawing on Bakhtin to move from critique to design. Language and Education, 17(3): 192-207.

Long, P. 2014. Staff and students' conceptions of good written feedback: Implications for practice. Practitioner Research in Higher Education, 8(1): 54-63.

Loqo, T. 2017. Academic staff perceptions and challenges in technology integration: A case study of Walter Sisulu University. European Conference on e-Learning. 318-325.

Lunt, T. \& Curran, J. 2010. 'Are you listening please?' The advantages of electronic audio feedback compared to written feedback. Assessment \& Evaluation in Higher Education, 35(7): 759-769.

Mckinley, J. 2015. Critical argument and writer identity: Social constructivism as a theoretical framework for EFL academic writing. Critical Inquiry in Language Studies, 12(3): 184-207.

Melles, G. 2004. Understanding the role of language/culture in group work through qualitative interviewing. Qualitative Report, 9(2): 216-240.

Mignolo, W.D. 2007a. Delinking: The rhetoric of modernity, the logic of coloniality and the grammar of de-coloniality. Cultural Studies, 21(2-3): 449-514.

Mignolo, W.D. 2007b. Introduction: Coloniality of power and de-colonial thinking. Cultural Studies, 21(2-3): 155-167.

Mignolo, W.D. 2011. Epistemic disobedience and the decolonial option: A manifesto. Transmodernity: Journal of Peripheral Cultural Production of the Luso-Hispanic World, 1(2): 44-66.

Miller, C.M. \& Parlett, M. 1974. Up to the Mark: A Study of the Examination Game. Guildford: Society for Research into Higher Education.

Mohamedbhai, G. 2014. Massification in higher education institutions in Africa: Causes, consequences and responses. International Journal of African Higher Education, 1(1).

Mok, K.H. \& Neubauer, D. 2016. Higher education governance in crisis: A critical reflection on the massification of higher education, graduate employment and social mobility. Journal of Education and Work, 29(3): 238-248.

Muller, J. 2014. Every picture tells a story: Epistemological access and knowledge. Education as Change, 18(2):255-269.

Nakata, M., Nakata, V., Keech, S. \& Bolt, R. 2012. Decolonial goals and pedagogies for indigenous studies. Decolonization: Indigeneity, Education \& Society, 1(1):120-140.

Poort, I., Jansen, E. \& Hofman, A. 2019. Intercultural group work in higher education: Costs and benefits from an expectancy-value theory perspective. International Journal of Educational Research, 93: 218-231.

Reeves, T.C., Herrington, J. \& Oliver, R. 2005. Design research: A socially responsible approach to instructional technology research in higher education. Journal of Computing in Higher Education, 16(2): 96-117. 
Sambell, K. \& Sambell, A. 2019. Developing autonomy via assessment for learning: students' views of their involvement in self and peer review activities. In Bryan, C. \& Clegg, K. (eds.) Innovative Assessment in Higher Education: A Handbook for Academic Practitioners. $2^{\text {nd }}$ ed. New York: Routledge, 173-189.

Shin, H. 2006. Rethinking TESOL from a SOL's perspective: Indigenous epistemology and decolonizing praxis in TESOL. Critical Inquiry in Language Studies, 3(2-3): 147-167.

Snyder, B.R. 1970. The Hidden Curriculum. Cambridge: MIT Press.

Smith, L.T. 2013. Decolonizing Methodologies: Research and Indigenous Peoples. New York: Zed Books.

Stahl, G.K., Mäkelä, K., Zander, L. \& Maznevski, M.L. 2010. A look at the bright side of multicultural team diversity. Scandinavian Journal of Management, 26(4): 439-447.

Sutherland, K. 2010. Supporting scholarly tutors to conduct effective tutorials. In Cantwell, R.H. and Scevak, J.J. (eds.) An Academic Life: A Handbook for New Academics. Camberwell: ACER Press, 65-74.

Topping, K.J. 2005. Trends in peer learning. Educational Psychology, 25(6): 631-645.

Vandeyar, S. \& Swart, R. 2019. Shattering the silence: dialogic engagement about education protest actions in South African university classrooms. Teaching in Higher Education, 24(6):772-788.

Volet, S.E. \& Ang, G. 2012. Culturally mixed groups on international campuses: An opportunity for inter-cultural learning. Higher Education Research \& Development, 31(1):21-37.

Vorster, J.A. \& Quinn, L. 2017. The" decolonial turn": What does it mean for academic staff development? Education as Change, 21(1):31-49.

Wang, F. \& Hannafin, M.J. 2005. Design-based research and technology-enhanced learning environments. Educational Technology Research and Development, 53(4): 5-23.

Winstone, N.E. \& Nash, R.A. 2019. 11 Developing students' proactive engagement with feedback. Innovative Assessment in Higher Education: A Handbook for Academic Practitioners: 129.

Winstone, N.E. \& Carless, D. 2020. Designing Effective Feedback Processes in Higher Education: A Learning Focused Approach. New York: Routledge.

Young, A. \& Fry, J.D. 2008. Metacognitive awareness and academic achievement in college students. Journal of the Scholarship of Teaching and Learning, 8(2):1-10.

Young, M. \& Muller, J. 2013. On the powers of powerful knowledge. Review of Education, 1(3): 229250. 